un rescate, y a la postre fue interesante escuchar esta obra que, sin embargo, es bastante dispareja. La formación europea de Giarda es evidente: orquestación impecable, sentido de la armonía, firme construcción temática. Pero la obra, en sus tres movimientos, no desarrolla completamente su material, a veces salta de una idea a otra sin lógica alguna, o se diluye sin solución, incluso al final, cuando de la nada aparece un brevísimo coro sin palabras, elemento que parecía perfectamente prescindible.

\title{
XXI Encuentro de Música Chilena Contemporánea
}

\author{
por \\ Vladimir Barraza Jeraldo \\ Conservatorio de Música, Universidad Austral de Chile, Chile \\ vbarraza@uach.cl
}

Entre el miércoles 24 y el viernes 26 de octubre de 2018 se desarrolló el XXI Encuentro de Música Chilena Contemporánea, que organiza el Conservatorio de Música de la Facultad de Arquitectura y Artes de la Universidad Austral de Chile

La música contemporánea chilena, como es tradicional en octubre en Valdivia, se tomó las aulas y escenarios del Conservatorio, en las salas Sergio Pineda y Aula Magna, iniciando el día miércoles con palabras de bienvenida del Director del Conservatorio de Música, Wladimir Carrasco, y del coordinador del evento, Sergio Berchenko. El encuentro fue financiado por el Fondo para el Fomento de la Música Nacional, convocatoria 2018.

Esta edición contó con la participación de un compositor-director de orquesta, un musicólogo, seis compositores y conjuntos musicales locales, especialmente integrados por alumnos y profesores del Conservatorio de Música de la UACh. La comisión organizadora del evento, conformada por profesores del Conservatorio de la Universidad Austral de Chile, escogió a los invitados o a sus obras para el encuentro sobre la base de su trayectoria musical o musicológica. De este modo, entre aquellos no residentes en Valdivia participaron el musicólogo Álvaro Menanteau y seis compositores: Juan Manuel Quinteros, Jaime Andrés Ramos, Rodrigo Castellanos, Sebastián Vergara y Guillermo Rifo (quien también se desempeñó como director de orquesta). Se incluyó también al compositor Felipe Pinto d'Aguiar, director de la Escuela de Artes Musicales y Sonoras de la UACh, y al coordinador prof. Berchenko.

Entre el total, escuchamos veinte obras de compositores chilenos ${ }^{1}$. Además se realizaron ocho charlas y una mesa redonda. La mayoría de las obras interpretadas fueron compuestas en el siglo XXI, en los años 2009, 2011, 2013, 2017 y 2018, a excepción de Batucada Blue (1981) y Danza bajo un sol naciente (1997) de Víctor Biskupovic², fallecido ya hace una década y media.

En relación con las charlas, todas realizadas en la Sala Sergio Pineda, el miércoles 24 tuvimos la oportunidad de escuchar, a partir de las 10:30 hrs., la ponencia de Jaime

${ }^{1}$ El detalle de las obras chilenas interpretadas en este encuentro será publicado en el Cuadro sinóptico del próximo número de la Revista Musical Chilena, correspondiente al período desde octubre 2018 a marzo 2019.

2 Revisar In memoriam en Revista Musical Chilena LVI/198 (julio-diciembre, 2002), pp. 117-118. 
Ramos "La banda sonora de la rutina II: música electrónica". A las 11:45 hrs. Rodrigo Castellanos presentó "Electrónica en vivo en la música contemporánea: pensamiento creativo e identidad".

El jueves 25 iniciaron las actividades a las 9:30 hrs con la charla de Juan Manuel Quinteros "Sincretismo y Pensamiento Instrumental", basado en el ciclo de piezas solistas Manifiesto. Luego a las 11:00 hrs. siguió la charla de Felipe Pinto d'Aguiar "Emergencias Musicales", y finalmente a las 12:30 hrs. Sebastián Vergara presentó "Máquinas: Tecnología y proceso creativo".

El viernes 26, último día de este encuentro, a las 9:30 hrs. se realizó la charla "Prosodia: Fonología, Métrica, Música” de Jaime Ramos. Luego a las 11:00 hrs., Álvaro Menanteau expuso el tema "Presencia española y latina en los orígenes del jazz: el ritmo de habanera". Finalmente se realizó una mesa redonda titulada "Pensamiento creativo e identidades del sur”, en la que participaron Felipe Pinto d'Aguiar, Juan Manuel Quinteros, Jaime Ramos, Rodrigo Castellanos y Sebastián Vergara. Su moderador fue Álvaro Menanteau.

A las 19:30 hrs. se llevó a cabo el concierto de clausura del encuentro en la Sala Aula Magna de la UACh. El director del Conservatorio, prof. Carrasco, y el coordinador del encuentro dirigieron emotivas palabras de agradecimientos y de despedida, especialmente a los invitados. El acto contó con la participación del Cuarteto de Alumnos del Conservatorio de Música UACh, y de la Orquesta de Alumnos del Conservatorio de Música UACh, bajo la dirección de Guillermo Rifo.

\title{
Primer Encuentro de Trabajadores de la Música
}

\author{
por \\ Vladimir Barraza Jeraldo \\ Conservatorio de Música \\ Universidad Austral de Chile, Chile \\ vbarraza@uach.cl
}

El 1 de noviembre de 2018, entre las 9:30 y las 18:30 hrs. se desarrolló el Primer Encuentro de Trabajadores de la Música, organizado por la Radio de la Universidad Austral de Chile (90.1 F.M.) y el sello discográfico Misisipi, representado por Javier Aravena. Se realizó en la sala Sergio Pineda del Conservatorio de Música de la Universidad Austral de Chile.

El encuentro se inició con palabras del director del conservatorio, Sr. Wladimir Carrasco, el director de la radio UACh, Sr. Miguel Millar, y el director del sello discográfico Misisipi, Sr. Javier Aravena.

Esta iniciativa tuvo entre sus principales objetivos reunir a representantes de músicos populares, clásicos y mapuches, especialmente de la Región de Los Ríos, para abordar en conjunto temas relacionados con la labor que desarrollan especialmente los músicos populares y que se conectan directamente con sus condiciones laborales, seguridad social, redes de fortalecimiento y posible formación de agrupaciones.

Se llevó a cabo una exposición titulada "La economía alrededor de los músicos", dictada por Helen Urra, periodista, encargada de la unidad de Fomento de las Artes e Industrias Creativas del Consejo Nacional de la Cultura y las Artes (CNCA), y por Marcelo Vera, ingeniero agrónomo y experto en negocios, además de exdirector de ProChile, institución encargada de promover las exportaciones de productos y servicios del país. 